Switching maintenance infliximab therapy to biosimilar infliximab in inflammatory bowel disease patients

\title{
Eberl, Anja
}

2017

Eberl , A , Huoponen , S , Pahikkala , T , Blom , M , Arkkila , P \& Sipponen , T 2017 , ' Switching maintenance infliximab therapy to biosimilar infliximab in inflammatory bowel disease patients ' , Scandinavian Journal of Gastroenterology , vol. 52 , no. 12 , pp. 1348-1353 . https://doi.org/10.1080/00365521.2017.1369561

http://hdl.handle.net/10138/308455

https://doi.org/10.1080/00365521.2017.1369561

unspecified

acceptedVersion

Downloaded from Helda, University of Helsinki institutional repository.

This is an electronic reprint of the original article.

This reprint may differ from the original in pagination and typographic detail.

Please cite the original version. 


\title{
Switching maintenance infliximab therapy to biosimilar infliximab in inflammatory bowel disease patients
}

\author{
Anja Eberl ${ }^{1}$, Saara Huoponen ${ }^{2}$, Tapio Pahikkala ${ }^{3}$, Marja Blom² ${ }^{2}$ Perttu Arkkila ${ }^{1 *}$, \\ Taina Sipponen ${ }^{1 *}$ \\ ${ }^{1}$ Gastroenterology, University of Helsinki and Helsinki University Hospital, Helsinki, \\ ${ }^{2}$ Faculty of Pharmacy, Division of Pharmacology and Pharmacotherapy, University of \\ Helsinki, Helsinki, Finland University of Helsinki, Helsinki, Finland \\ ${ }^{3}$ Department of Future Technologies, University of Turku, Turku, Finland \\ *Authors share equal contribution
}

Short title: Switching maintenance infliximab to biosimilar one

Corresponding author:

Anja Eberl, M.D

Department of Gastroenterology, Helsinki University Hospital

Box 340

FIN-00029 HUS

Tel. +358-504270190

Email : anja.eberl@hus.fi 


\section{Switching maintenance infliximab therapy to biosimilar infliximab in inflammatory bowel disease patients}

\section{Abstract:}

Background: Clinical use of biosimilar infliximab (CT-P13) in inflammatory bowel diseases (IBDs) is based on extrapolation of indication from clinical studies performed in rheumatological diseases. Only few data exist of behaviour of infliximab trough levels (TLs) and anti-drug antibodies (ADAs) during switching.

Aim: The objective of this study was to evaluate changes in TLs, ADA formation and disease activity after switching from originator infliximab to biosimilar one.

Methods: All our IBD patients receiving maintenance infliximab therapy were switched to biosimilar infliximab. TLs and ADAs were measured before the last originator infusion and before the third biosimilar infusion. Laboratory values, disease activity indices (Partial Mayo Score and Harvey-Bradshaw Index) and demographic data were collected from patient records.

Results: A total of 62 patients were included in the final analysis (32 Crohn's disease, 30 ulcerative colitis (UC) or IBD-unclassified). No significant changes in median TLs before $(5.5 \mathrm{mg} / \mathrm{l})$ and after switching $(5.5 \mathrm{mg} / \mathrm{l}, \mathrm{p}=0.05)$ occurred in the entire study group or in the Crohn's disease subgroup (5.75mg/l and $6.5 \mathrm{mg} / \mathrm{l}, \mathrm{p}=0.68)$. However, in the subgroup of ulcerative colitis, the change in median TL was significantly different (from 5.2 to $4.25 \mathrm{mg} / \mathrm{l}, \mathrm{p}=0.019$ ). Two patients developed ADAs after switching. No changes in disease activity were detected during switching and no safety concerns occurred.

Conclusions: Switching from originator to biosimilar infliximab resulted in statistically significant differences in infliximab TLs in patients with UC but not in patients with 
Crohn's disease. The clinical significance for this difference is doubtful and in neither group changes in disease activity occurred.

Keywords : infliximab, biosimilar, CT-P13, Crohn's disease, ulcerative colitis, trough levels, TNF- $\alpha$ antagonist. 


\section{Introduction}

The use of chimeric monoclonal antibody (IgG1) infliximab (IFX) against TNF- $\alpha$ has emerged since the FDA approval in 1998 for the treatment of Crohn's disease (CD) and in 2005 for ulcerative colitis (UC) [1]. IFX is effective in both children and adults with moderate to severe $\mathrm{CD}$ and UC in inducing and maintaining remission [2-6]. However, a considerable number of patients either fail to respond to TNF- $\alpha$-antagonists (primary non-responders) or lose response over time (secondary loss of response). Formation of anti-drug antibodies (ADAs) is an important cause for secondary loss of response [7]. IFX trough levels (TLs) and ADAs can be measured from patients' serum samples by using commercial available immunoassays. These measurements are valuable tools in optimizing IFX therapy [8-10]. Recently, ADA crossreactivity between originator IFX and CT-P13 has been described [11].

In June 2013, the European Medical Agency (EMA) accepted IFX biosimilar (CT-P13) for all indications of the originator product [12]. For CD and UC, the indication was extrapolated from studies showing efficacy of biosimilar IFX in ankylosing spondylitis and rheumatoid arthritis $[13,14]$. This extrapolation of indication raised concern among national and international IBD societies regarding the safety and interchangeability of biosimilars [15]. In IBD patients only limited data were available of the efficacy and safety of CT-P13 until recently. First real-life data of CT-P13 in induction therapy for IBD patients and switching from originator has recently been published [16-25].

The aim of our study was to evaluate changes in TLs, ADA formation and disease activity after switching from originator to biosimilar IFX during IBD maintenance therapy. 


\section{Patients and Methods}

\subsection{Switching programme design}

All IBD patients receiving IFX (Remicade ${ }^{\mathrm{TM}}$, Janssen Biotech, Inc/ Schering-Plough, EU) maintenance therapy at Helsinki University Hospital were switched to biosimilar IFX (Remsima $^{\text {TM }}$, Celltrion Pharm, Inc., South Korea) in the beginning of year 2016. IFX TLs and ADAs were measured before the last originator IFX infusion (baseline) and before the third biosimilar IFX infusion (follow-up). Blood samples for measurements of haemoglobin, leukocytes, platelets and serum C-reactive protein (CRP) were also taken at these time points. Faecal calprotectin (FC), Partial Mayo Score (PMS) and Harvey Bradshaw index (HBI) were used to assess clinical disease activity [26,27].

IFX TLs were measured with capture-ELISA (Promonitor EIA, Progenica) at United Medix Laboratories (Helsinki, Finland) and the levels of ADAs were analyzed with fluid-phase radioimmunoassay (Sanguin Laboratories, The Netherlands). IFX TLs below $0.03 \mathrm{mg} / \mathrm{l}$ and ADAs below 12 AU/ml were considered non-detectable. Patients having an originator IFX TL below or above the target level $3-7 \mathrm{mg} / 1$ [8] and needing dose adjustment were excluded from paired analyses.

FC was measured in the routine clinical laboratory by a quantitative enzyme immunoassay (PhiCal Test, Calpro AS, Oslo, Norway) and the values quoted as normal were $<100 \mu \mathrm{g} / \mathrm{g}$ of stool [28].

\subsection{Statistical analyses}

Laboratory values are presented as median and interquartile Range (IQR). Disease activity is presented as mean and standard deviation (SD). Wilcoxon Signed-Rank test served as exploring changes between related variables. For further analysis of TLs, we used the nonparametric two 
one-sided test of equivalence for paired samples [29]. Equivalence was established if the 95\% confidence interval (CI) of the median difference in the TLs before and after switching fell within the equivalence boundaries. The boundaries were set to $+/-$ the median absolute deviation about the median of the baseline IFX TL of all patients, indicating that the change of TL after switch for a patient tends to be smaller than the baseline TL difference between the patients. Matplotlib version 1.5.1. was used for figure-drawing. Significance was set at 0.05.

\subsection{Ethical considerations}

The change of maintenance originator IFX to biosimilar IFX and measurements of TLs and ADAs occurred as a part of the routine clinic work based on the hospital's medical decisions. The study was approved by the ethics committee of the Helsinki University Hospital (Dnro 32/13/03/01/2016) and research study permission was received from the Hospital District of Helsinki and Uusimaa (HUS-170-2016-2).

\section{Results}

\subsection{Patients and infliximab trough levels}

Switching from maintenance originator IFX to biosimilar IFX occurred in 78 patients $(38 \mathrm{CD}$, 37 UC and 3 IBD-unclassified [IBD-u]). Because of the small number of IBD-u patients, the data of UC and IBD-u patients were pooled. During maintenance originator IFX therapy, 47 of $78(60.5 \%)$ had a TL below $(n=16)$ or above $(n=31)$ the target trough concentration $3-7 \mathrm{mg} / 1$. Based on these baseline IFX TLs and clinical evaluation, 14 (17.9\%) patients underwent dose adjustment (nine with a TL below $3 \mathrm{mg} / \mathrm{l}$ and five with a TL above $7 \mathrm{mg} / \mathrm{l}$ ) and were excluded from the paired concentration analyses. Two patients were excluded because of changes in the infusion regime due to non-medical reasons.

Paired IFX TL and ADA measurements, clinical and laboratory data were available of 62 patients (32 CD, $30 \mathrm{CU} / \mathrm{IBD}-\mathrm{u})$ (Table 1). All UC patients had either left-sided colitis or 
extensive colitis. The majority of CD patients had an ileocolic involvement (20 patients, $62.5 \%)$. Of $32 \mathrm{CD}$ patients, $20(62.5 \%)$ and of $30 \mathrm{UC}$ patients $24(80 \%)$ used concomitant immunomodulators. Median IFX infusion interval was 8 weeks (range 4 - 10 weeks).

During maintenance therapy with originator IFX, the median IFX TL of 62 patients was 5.5 mg/l (IQR $3.85 \mathrm{mg} / \mathrm{l}$ - $8.65 \mathrm{mg} / \mathrm{l})$. The median follow-up IFX TL was $5.5 \mathrm{mg} / \mathrm{l}$ (IQR $3.15 \mathrm{mg} / \mathrm{l}$ - $7.8 \mathrm{mg} / \mathrm{l})$. The median TL difference was $0.45 \mathrm{mg} / \mathrm{l}$. There was no statistically significant change $(\mathrm{p}=0.05)$ in TLs before and after switching (Figure 1 and 2).

We also analysed the data separately for CD and UC. For CD patients, the median IFX TL was $5.75 \mathrm{mg} / \mathrm{l}(\mathrm{IQR} 4.48 \mathrm{mg} / \mathrm{l}-8.4 \mathrm{mg} / \mathrm{l})$ before and $6.5 \mathrm{mg} / \mathrm{l}(\mathrm{IQR} 3.98 \mathrm{mg} / \mathrm{l}-8.35 \mathrm{mg} / \mathrm{l})$ after switch and no statistical significant difference was detected $(\mathrm{p}=0.68)$. The median TL difference in the CD subgroup was $0.4 \mathrm{mg} / \mathrm{l}$ (see Figure 3a). However, in UC/IBD-u patients the change in median IFX TLs before and after switching was statistically significant: from median baseline TL $5.2 \mathrm{mg} / \mathrm{l}$ (IQR $3.8 \mathrm{mg} / \mathrm{l}-8.65 \mathrm{mg} / \mathrm{l})$ to follow-up TL $4.25 \mathrm{mg} / \mathrm{l}$ (IQR $2.6 \mathrm{mg} / \mathrm{l}$ $6.45 \mathrm{mg} / \mathrm{l}, \mathrm{p}=0.019$ ). The median TL difference was $0.9 \mathrm{mg} / \mathrm{l}$ (see Figure $3 \mathrm{~b}$ ).

When analysing these data further we noticed that the difference between baseline and followup TL in UC patients was mainly due to four patients that had TL difference greater than 3.2 $\mathrm{mg} / \mathrm{l}$. One of them had an undetectable TL with measurable ADAs after switching (baseline and follow-up TL $7.4 \mathrm{mg} / \mathrm{l}$ and $<0.03 \mathrm{mg} / \mathrm{l}$, respectively, and ADA $35 \mathrm{AU} / \mathrm{ml}$ ) and experienced a clinical disease relapse. Another patient with a great TL difference $(11 \mathrm{mg} / \mathrm{l}$ before and 3.1 $\mathrm{mg} / \mathrm{l}$ after switch) discontinued azathioprine medication a few weeks before the measurement of follow-up TL, which might at least partly explain the difference. For the other two patients, there was no obvious reason for the TL difference. These three patients remained in clinical remission. 


\subsection{Anti-drug antibodies}

At baseline ADAs were detectable only in one of $78(1.3 \%)$ patient with a titre of $18 \mathrm{AU} / \mathrm{ml}$. Because of an IFX dose adjustment that patient was excluded from final paired analysis, but in follow-up after shortening of IFX interval the ADAs were undetectable. After switching, one patient on IFX monotherapy and one on a combination therapy with azathioprine developed ADAs (titres12 AU/ml and $35 \mathrm{AU} / \mathrm{ml}$, respectively).

\subsection{Disease activity}

Disease activity at baseline and follow-up is shown in Table 2. Mean HBI was 1.22 (SD 2.29) before and 1.16 (2.22) after switching. Mean PMS was 1.2 (SD 1.76) before and 0.8 (SD 1.28) after switching. The disease activity during switching neither in UC nor in CD showed statistical difference $(\mathrm{p}=0.89$ and $\mathrm{p}=0.07)$. In the whole study group, median $\mathrm{FC}$ concentration was $69 \mu \mathrm{g} / \mathrm{g}$ (IQR $10-251 \mu \mathrm{g} / \mathrm{g}$ ) before and $26 \mu \mathrm{g} / \mathrm{g}$ (IQR $13-180 \mu \mathrm{g} / \mathrm{g}$ ) after switching $(\mathrm{p}=0.78)$. Rate of infusion reactions was low after switching (4 out of 156 infusions, $2.5 \%$ ): There was one reaction during biosimilar IFX infusion (throat sensation) and three potentially infusion related adverse effects after the first or second biosimilar infusion (rash, headache and nausea, fever and diarrhea). None of these effects resulted in discontinuation of the therapy.

\section{Discussion}

In this single-centre observational study all IBD patients receiving maintenance IFX therapy were switched to biosimilar IFX without any effects on IBD activity. Switching caused no statistically significant differences in IFX TLs in the whole IBD group or in CD subgroup. In the UC subgroup, however, TLs were statistically significantly lower after switching. 
Since year 2013 EMA approval, evidence of biosimilar infliximab use in extrapolated indications, such as IBD has accumulated. In this study where all IBD patients on maintenance originator infliximab were switched to biosimilar one, we observed no differences in disease activity, laboratory values, infusion reactions and adverse effects. Our findings are in line with results from recently published studies [19-25]. Razanskaite and co-workers found no significant differences between originator and CT-P13 in terms of drug persistence, side effects, adverse effects, disease activity, or blood tests. TLs and ADAs did not show significant difference before and after switch [19]. Smits and co-workers showed that switching to biosimilar IFX led to a nonsignificant slight increase in median TL at week 16 (from $3.6 \mathrm{ug} / \mathrm{ml}$ at week 0 to $4.2 \mathrm{ug} / \mathrm{ml})$, but not at week $52(3.6 \mathrm{ug} / \mathrm{ml}$ and $3.7 \mathrm{ug} / \mathrm{ml})$. There was no effect on disease activity [20,21]. Also in the study of Buer and co-workers disease activity, laboratory values and IFX TL remained stable in a six months follow-up period after switching [23]. In the large randomized NOR-SWITCH study no significant differences were observed one year after switch in clinical activity indices, serum CRP, FC or TLs in UC patients. In CD patients, changes in patient's and physician's global assessment of disease activity showed some improvement in those receiving originator IFX compared to those on biosimilar IFX [24]. Different from the NOR-SWITCH results, we detected significantly lower TLs after switching in UC patients. Although this difference is statistically significant, the clinical relevance of this finding remains unclear and should be interpreted with caution because of the rather low patient number in the UC subgroup. We point out that no changes in disease clinical activity occurred and a constantly low FC concentration in these patients suggested a stable remission after switching. As the follow up time in our study was only 16 weeks we cannot make any further statement about the behaviour of patients' TLs and ADA development after that period. It is known that the clearance of biologicals is influenced by various patient dependent factors like weight, disease severity, concomitant medication, albumin, and other pharmacokinetic and 
pharmacodynamic factors [30,31]. Furthermore, the use of a concomitant immunosuppressive medication is a well-known factor that reduces the clearance of IFX, increases trough concentrations and reduces the risk of ADA formation [32]. In current study, however, the use of concomitant immunomodulators does not explain the observed differences in TLs in UC patients, because the use of these medications was even higher in the UC than in the CD subgroup. Another limitation of our study was a lack of a control group continuing on originator IFX. Therefore, it remains unresolved whether the change in median TL in UC patients is due to switching to the biosimilar IFX or due to other patient dependent or pharmacological factors. It is unlikely that the difference in IFX TLs could be explained by the ELISA test used. It has been shown in a recent real-life study, that the ELISA tests used for measuring originator IFX TLs and ADAs are feasible also for biosimilar IFX measurements [33].

During maintenance IFX therapy over a half of the patients in our study had TLs either below or above the suggested target level of 3 to $7 \mathrm{mg} / \mathrm{l}$. This parallels the results of the TAXIT trial, where $43.7 \%$ of patients on maintenance IFX therapy had a TL between 3 and $7 \mathrm{mg} / \mathrm{l}$ [8]. In that trial either reducing IFX dose in patients in clinical remission with TL over the target level or dose escalation in those with a low TL was safe and feasible. In our study de-escalation in clinically stable patients occurred less often that dose escalation. Recently published data suggest that even higher target TL for infliximab than that used in the TAXIT trial should be obtained especially in perianal CD: patients with fistula healing had significantly higher median serum IFX levels $(15.8 \mathrm{mg} / \mathrm{l})$ than those with active fistulas $(4.4 \mathrm{mg} / \mathrm{l})$ [34].

The amount of infusion related reactions and potential adverse effects was low in our study (2.5\% of infusions). No severe adverse effects were reported. All patients continued therapy with the biosimilar IFX. Thus, in IBD patients being in stable remission, switching from maintenance originator IFX therapy to biosimilar one seems to be safe. 
To conclude, in this study, TLs before and after switch did not differ significantly in CD patients, but a statistically significant decrease in TLs in UC patients occurred. The clinical relevance of this decrease remains unclear as we could not observe any changes in clinical disease activity or faecal calprotectin. No safety concerns occurred during switching.

\section{Acknowledgments}

The authors had no writing assistance. Anja Eberl participated in the design of the study, carried out some of the data analyses and drafted and critically revised the manuscript. Saara Huopanen participated in the design of the study, drafted and critically revised the manuscript. Tapio Pahikkala carried out the data analysis. Marja Blom and Perttu Arkkila participated in the design of the study, drafted and critically revised the manuscript critically revised the manuscript. Taina Sipponen participated in the design of the study, carried out the data analyses in part and critically revised the manuscript. All authors read and approved the final manuscript.

There is no conflict of financial interests. 


\section{References}

1. Kornbluth A. Infliximab approved for use in Crohn's disease: a report on the FDA GI Advisory Committee conference. Inflamm Bowel Dis. 1998;4:328-9.

2. Hyams J, Crandall W, Kugathasan S, et al. Induction and maintenance infliximab therapy for the treatment of moderate-to-severe Crohn's disease in children. Gastroenterology. 2007;132:863-73; quiz 1165-6. Epub 2006/12/03.

3. Hyams J, Walters TD, Crandall W, et al. Safety and efficacy of maintenance infliximab therapy for moderate-to-severe Crohn's disease in children: REACH open-label extension. Curr Med Res Opin. 2011;27:651-62. Epub 2011/01/18.

4. Rutgeerts P, Sandborn WJ, Feagan BG, et al. Infliximab for induction and maintenance therapy for ulcerative colitis. N Engl J Med. 2005;353:2462-76.

5. Eidelwein AP, Cuffari C, Abadom V, et al. Infliximab efficacy in pediatric ulcerative colitis. Inflamm Bowel Dis. 2005;11:213-8.

6. McGinnis JK, Murray KF. Infliximab for ulcerative colitis in children and adolescents. J Clin Gastroenterol. 2008;42:875-9.

7. Vande Casteele N, Khanna R, Levesque BG, et al. The relationship between infliximab concentrations, antibodies to infliximab and disease activity in Crohn's disease. Gut. 2015;64:1539-45. Epub 2014/10/21.

8. Vande Casteele N, Ferrante M, Van Assche G, et al. Trough concentrations of infliximab guide dosing for patients with inflammatory bowel disease. Gastroenterology. 2015;148:1320-9.e3. Epub 2015/02/24.

9. Afif W, Loftus EV, Faubion WA, et al. Clinical utility of measuring infliximab and human anti-chimeric antibody concentrations in patients with inflammatory bowel disease. Am J Gastroenterol. 2010;105:1133-9. Epub 2010/02/09.

10. Yanai H, Hanauer SB. Assessing response and loss of response to biological therapies in IBD. Am J Gastroenterol. 2011;106:685-98. Epub 2011/03/22.

11. Ben-Horin S, Yavzori M, Benhar I, et al. Cross-immunogenicity: antibodies to infliximab in Remicade-treated patients with IBD similarly recognise the biosimilar Remsima. Gut. 2016;65:1132-8. Epub 2015/04/20.

12. European Medicines Agency, Committee for Medicinal Products for Human Use. Assessment Report. 2013. http://www.ema.europa.eu/docs/en_GB/document_library/EPAR_Public_assessment_report/human/002576/WC500151486.pdf

13. Park W, Hrycaj P, Jeka S, et al. A randomised, double-blind, multicentre, parallelgroup, prospective study comparing the pharmacokinetics, safety, and efficacy of CT-P13 and innovator infliximab in patients with ankylosing spondylitis: the PLANETAS study. Ann Rheum Dis. 2013;72:1605-12. Epub 2013/05/16.

14. Yoo DH, Hrycaj P, Miranda P, et al. A randomised, double-blind, parallel-group study to demonstrate equivalence in efficacy and safety of CT-P13 compared with innovator infliximab when coadministered with methotrexate in patients with active rheumatoid arthritis: the PLANETRA study. Ann Rheum Dis. 2013;72:1613-20. Epub 2013/05/16. 15. Danese $\mathrm{S}$, Gomollon F, ECCO GBaOBo. ECCO position statement: the use of biosimilar medicines in the treatment of inflammatory bowel disease (IBD). J Crohns Colitis. 2013;7:586-9. Epub 2013/04/25.

16. Gecse KB, Lovász BD, Farkas K, et al. Efficacy and Safety of the Biosimilar Infliximab CT-P13 Treatment in Inflammatory Bowel Diseases: A Prospective, Multicentre, Nationwide Cohort. J Crohns Colitis. 2016;10:133-40. Epub 2015/12/10.

17. Jung YS, Park DI, Kim YH, et al. Efficacy and safety of CT-P13, a biosimilar of infliximab, in patients with inflammatory bowel disease: A retrospective multicenter study. J Gastroenterol Hepatol. 2015;30:1705-12. 
18. Fiorino G, Manetti N, Armuzzi A, et al. The PROSIT-BIO Cohort: A Prospective Observational Study of Patients with Inflammatory Bowel Disease Treated with Infliximab Biosimilar. Inflamm Bowel Dis. 2017;23:233-43. Epub 2017/01/17.

19. Razanskaite V, Bettey M, Downey L, et al. Biosimilar Infliximab in Inflammatory Bowel Disease: Outcomes of a Managed Switching Programme. J Crohns Colitis. 2017. Epub 2017/01/27.

20. Smits LJ, Derikx LA, de Jong DJ, et al. Clinical Outcomes Following a Switch from Remicade ${ }^{\circledR}$ to the Biosimilar CT-P13 in Inflammatory Bowel Disease Patients: A Prospective Observational Cohort Study. J Crohns Colitis. 2016;10:1287-93. Epub 2016/04/19.

21. Smits LJT, Grelack A, Derikx L, et al. Long-Term Clinical Outcomes After Switching from Remicade(R) to Biosimilar CT-P13 in Inflammatory Bowel Disease. Dig Dis Sci. 2017. Epub 2017/07/02.

22. Arguelles-Arias F, Guerra Veloz MF, Perea Amarillo R, et al. Effectiveness and Safety of CT-P13 (Biosimilar Infliximab) in Patients with Inflammatory Bowel Disease in Real Life at 6 Months. Dig Dis Sci. 2017;62:1305-12. Epub 2017/03/11.

23. Buer LC, Moum BA, Cvancarova M, et al. Switching from Remicade(R) to Remsima(R) is well Tolerated and Feasible: A Prospective, Open-label Study. J Crohns Colitis. 2017;11:297-304. Epub 2016/11/01.

24. Jorgensen KK, Olsen IC, Goll GL, et al. Switching from originator infliximab to biosimilar CT-P13 compared with maintained treatment with originator infliximab (NORSWITCH): a 52-week, randomised, double-blind, non-inferiority trial. Lancet. 2017;389:2304-16. Epub 2017/05/16.

25. Sieczkowska J, Jarzębicka D, Banaszkiewicz A, et al. Switching Between Infliximab Originator and Biosimilar in Paediatric Patients with Inflammatory Bowel Disease. Preliminary Observations. J Crohns Colitis. 2016;10:127-32. Epub 2015/12/30.

26. Best WR. Predicting the Crohn's disease activity index from the Harvey-Bradshaw Index. Inflamm Bowel Dis. 2006;12:304-10.

27. Lewis JD, Chuai S, Nessel L, et al. Use of the noninvasive components of the Mayo score to assess clinical response in ulcerative colitis. Inflamm Bowel Dis. 2008;14:1660-6. 28. Sipponen T, Kolho KL. Fecal calprotectin in diagnosis and clinical assessment of inflammatory bowel disease. Scand J Gastroenterol. 2015;50:74-80.

29. Mara CA, Cribbie RA. Paired-Samples Tests of Equivalence. Communications in Statistics - Simulation and Computation. 2012;41:1928-43. Epub 13 Jun 2012.

30. Dotan I, Ron Y, Yanai H, et al. Patient factors that increase infliximab clearance and shorten half-life in inflammatory bowel disease: a population pharmacokinetic study. Inflamm Bowel Dis. 2014;20:2247-59.

31. Vande Casteele N, Gils A. Pharmacokinetics of anti-TNF monoclonal antibodies in inflammatory bowel disease: Adding value to current practice. J Clin Pharmacol. 2015;55 Suppl 3:S39-50.

32. Vermeire S, Noman M, Van Assche G, et al. Effectiveness of concomitant immunosuppressive therapy in suppressing the formation of antibodies to infliximab in Crohn's disease. Gut. 2007;56:1226-31.

33. Schulze K, Koppka N, Lutter F, et al. CT-P13 (Inflectra, Remsima) monitoring in patients with inflammatory bowel disease. Biologicals. 2016;44:463-6.

34. Yarur AJ, Kanagala V, Stein DJ, et al. Higher infliximab trough levels are associated with perianal fistula healing in patients with Crohn's disease. Aliment Pharmacol Ther. 2017;45:933-40. 


\section{TABLES:}

Table 1: Patients Demographic and Baseline Characteristics

\begin{tabular}{|c|c|c|}
\hline & $C D(n=32)$ & $U C / I B D-u(n=30)$ \\
\hline Gender: Male, $n(\%)$ & $21(65.6)$ & 14(46.7) \\
\hline Age, years, median (IQR) & $35(28-45)$ & $37(31-43)$ \\
\hline Age at diagnosis, years, median (IQR) & $19(16-25)$ & $27(18-35)$ \\
\hline Duration of disease, years, median (IQR) & $13(9-24)$ & $9(5-13)$ \\
\hline \multicolumn{3}{|l|}{ Smoking, $n(\%)$} \\
\hline no & $19(59.4)$ & $25(83.3)$ \\
\hline yes & $8(25)$ & $1(3.3)$ \\
\hline former & $5(15.6)$ & $4(13.3)$ \\
\hline \multicolumn{3}{|l|}{ Montreal classification (\%) } \\
\hline$A 1, A 2, A 3$ & $9,22,1(28.1,68.8,3.1)$ & - \\
\hline$L 1, L 2, L 3, L 4$ & $5,7,20,5(15.6,21.9,62.5,15.6)$ & - \\
\hline$B 1, B 2, B 3$ & $14,10,8(43.8,31.3,25)$ & - \\
\hline Perianal disease & $8,(25)$ & - \\
\hline$E 2, E 3$ & - & $15(50), 15(50)$ \\
\hline Time using IFX, days, median (IQR) & $1544(531-2072)$ & $361(216-957)$ \\
\hline \multicolumn{3}{|l|}{ Concomitant medication $n(\%)$} \\
\hline Azathioprine & $16(50)$ & $18(60)$ \\
\hline 6-Mercaptopurin & $1(3.1)$ & $2(6.7)$ \\
\hline Methotrexate & $3(9.4)$ & $4(13.3)$ \\
\hline Mesalamine & $3(9.4)$ & $12(40)$ \\
\hline Corticosteroids & $1(3.1)$ & $2(6.7)$ \\
\hline
\end{tabular}

CD, Crohn's Disease; UC, Ulcerative Colitis; IBD-U, IBD-unclassified 
Table 2: Disease activity

\begin{tabular}{|c|c|c|c|c|c|c|}
\hline & \multicolumn{3}{|l|}{$C D(n=32)$} & \multicolumn{3}{|c|}{$U C / I B D-u(n=30)$} \\
\hline & Baseline & after switch & p-value & Baseline & after switch & $p$-value \\
\hline$H B I$, mean $(S D)$ & $1.22(2.29)$ & $1.16(2.22)$ & 0.89 & - & - & - \\
\hline$P M S$, mean $(S D)$ & - & - & - & $1.2(1.76)$ & $0.8(1.28)$ & 0.07 \\
\hline \multicolumn{7}{|l|}{ Calprotectin $\mu \mathrm{g} / \mathrm{g}$} \\
\hline median $(I Q R)$ & $22(10-189)$ & $17(5-312)$ & 0.35 & $82(9-270)$ & $32(20-169)$ & 0.54 \\
\hline \multicolumn{7}{|l|}{ Haemoglobin $\mathrm{g} / \mathrm{l}$} \\
\hline median $(I Q R)$ & $140(131-150)$ & $146(133-152)$ & 0.14 & $138(124-150)$ & $141(123-148)$ & 0.31 \\
\hline \multicolumn{7}{|l|}{ Leucocytes E9/l } \\
\hline median (IQR) & $6.7(6.1-7.8)$ & $6.7(6.2-7.8)$ & 0.21 & $7.0(5.0-7.9)$ & $6.1(5.0-7.5)$ & 0.16 \\
\hline \multicolumn{7}{|l|}{ Platelets E9/l } \\
\hline median (IQR) & $252(227-298)$ & $160(224-309)$ & 0.91 & $281(242-315)$ & $249(220-312)$ & 0.26 \\
\hline \multicolumn{7}{|l|}{$C R P m g / l$} \\
\hline median $(I Q R)$ & $3(3-3)$ & $3(3-5)$ & 0.875 & $3(3-3)$ & $3(3-3)$ & 0.577 \\
\hline
\end{tabular}

CD, Crohn's Disease; UC, Ulcerative Colitis; IBD-U, IBD-unclassified

HBI, Harvey-Bradshaw Index; PMS, Partial Mayo Score 
Figure legends:

Figure 1: Trough levels before (BASE IFX) and after (FU IFX) switching from originator to biosimilar infliximab in Crohn's disease (CD) patients. The dotted line presents the median trough level.

Figure 2: Trough levels before (BASE IFX) and after (FU IFX) switching from originator to biosimilar infliximab in ulcerative colitis (UC) patients. The dotted line presents the median trough level.

Figure 3a \& b: Distribution of trough level differences before (BASE IFX) and after (FU IFX) switching from originator infliximab (IFX) to biosimilar IFX in CD patients (a) and in UC patients (b).

The median differences and its $95 \%$ confidence intervals (CI) are marked with a solid dot and arrows. The difference is statistically significant $(\mathrm{p}<0.05)$ if zero is not covered by the interval between the arrows. Trough levels are considered equivalent if the interval between the arrows does not cross the equivalence margins shown with dashed vertical lines. 
Figure 1:

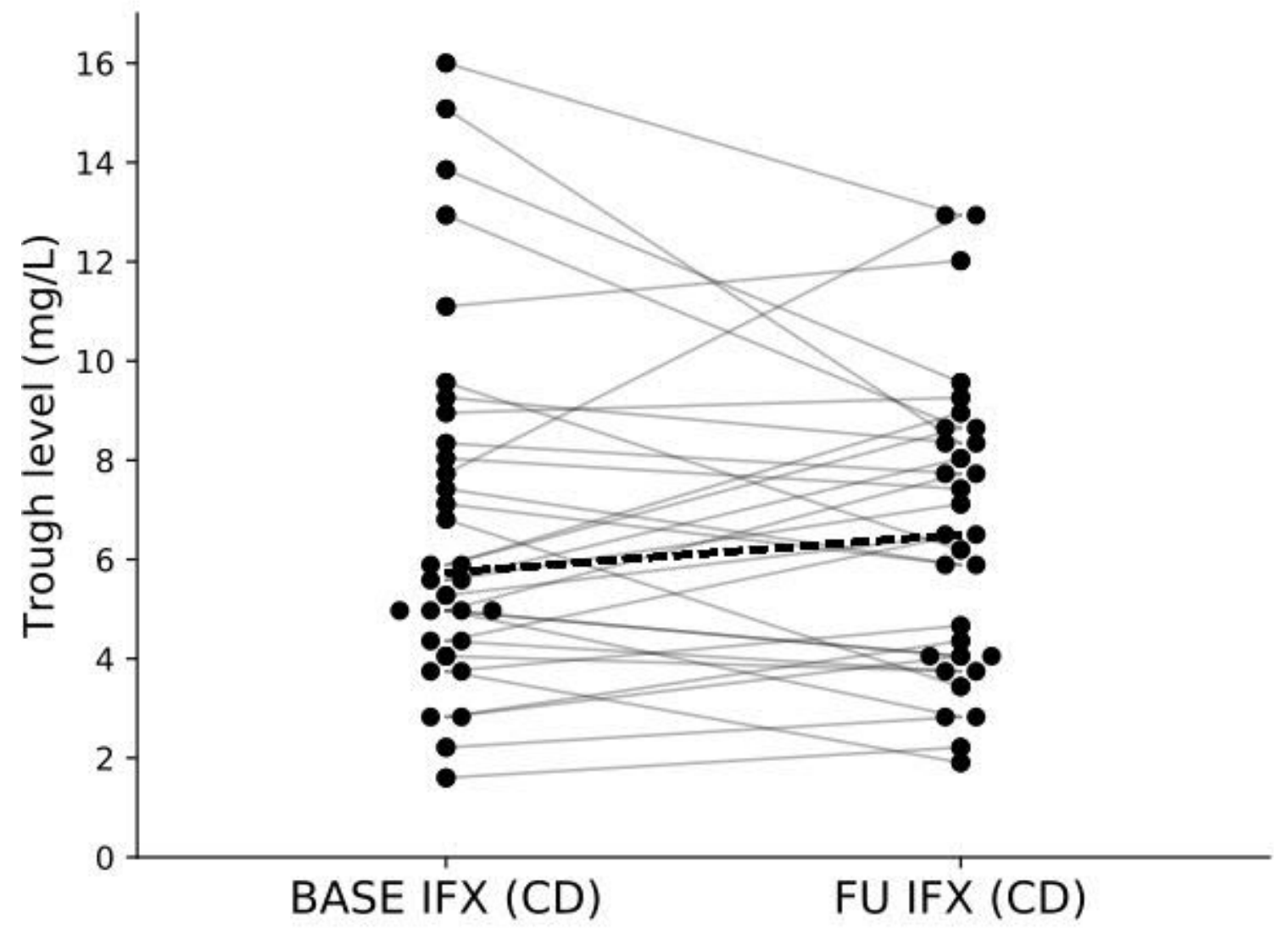


Figure 2:

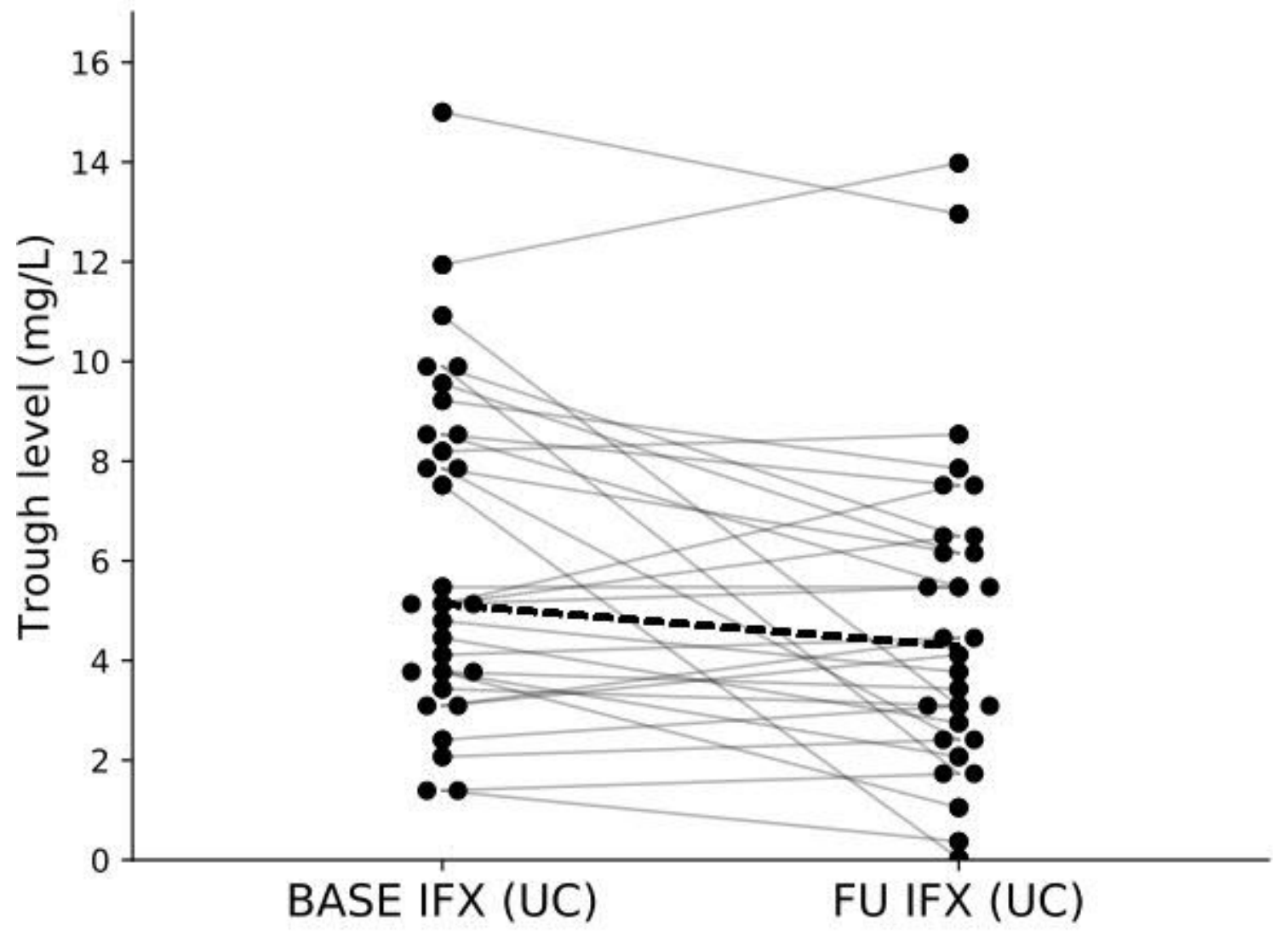


Figure 3a.

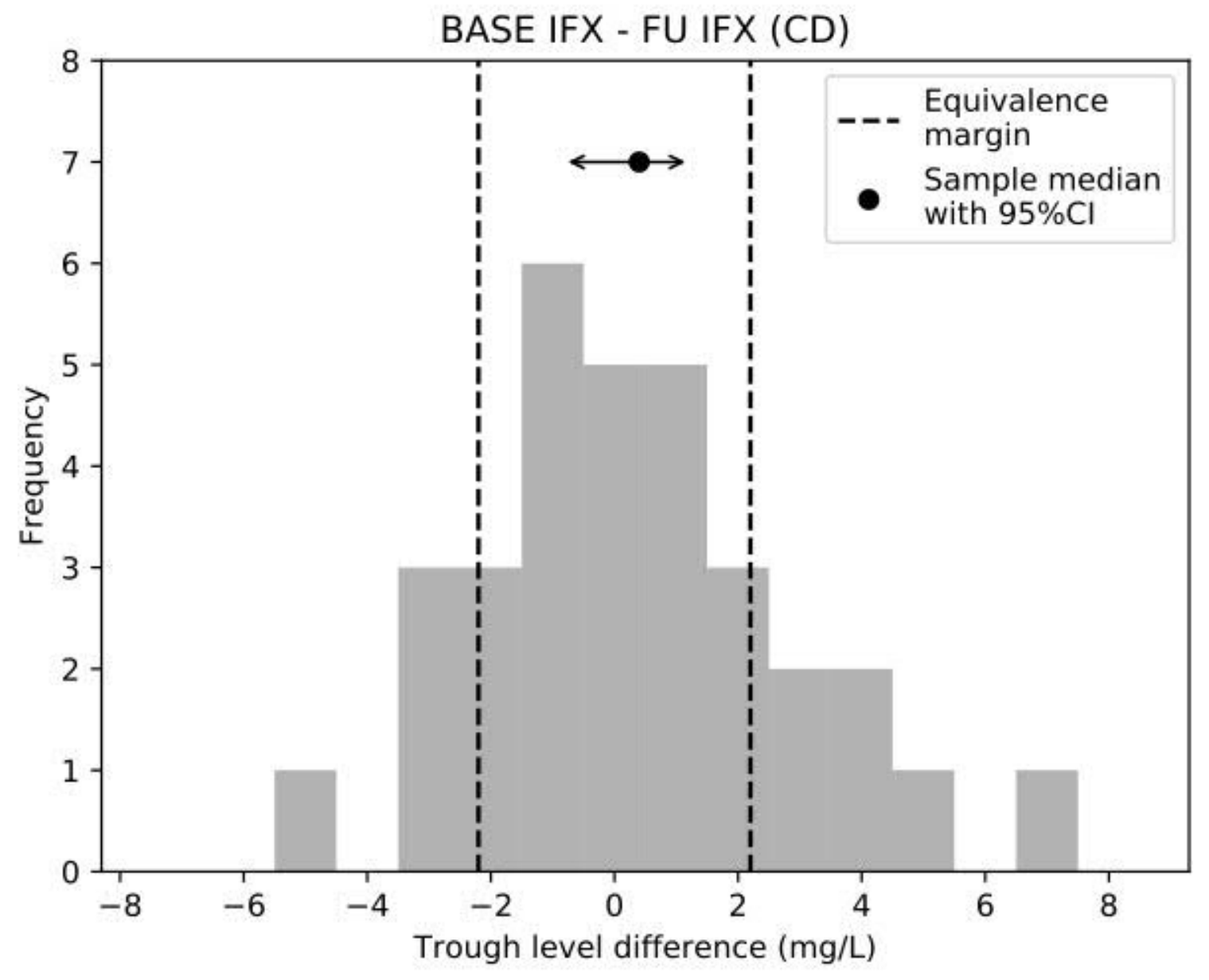


Figure $3 b$.

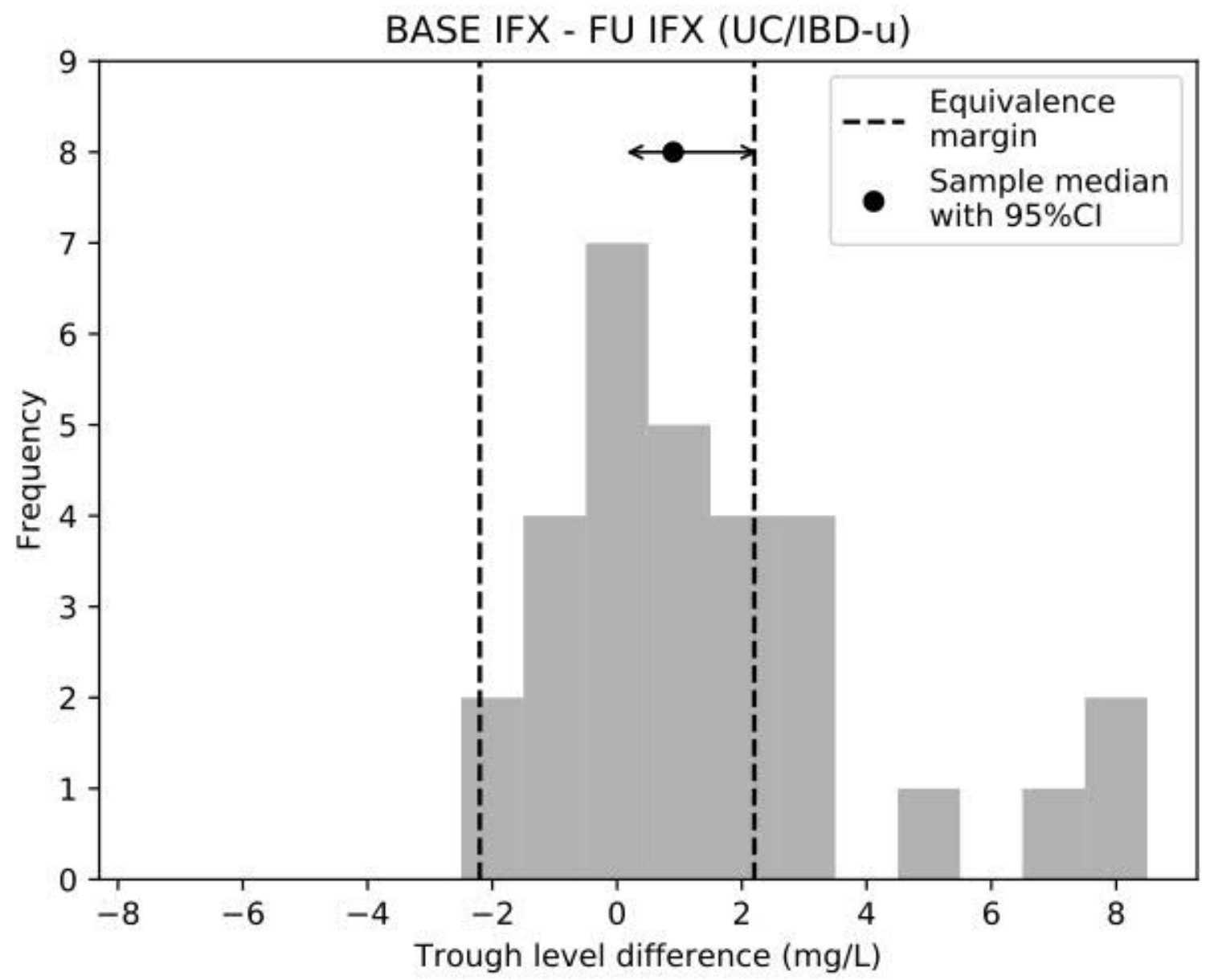


